\title{
SIMILARLY SITUATED UNDER THE SUNDAY CLOSING LAW
}

The Supreme Court in 1961 upheld the constitutionality of Sunday closing laws making classifications reasonably related to the legislative purpose of providing a day of work stoppage and rest. ${ }^{1}$ Subsequent attacks ${ }^{2}$ upon these laws have focused on the constitutional problems posed by their potential for discriminatory enforcement. That is,

whether in a community in which there is general disregard of a particular law with the acquiescence of the public authorities, the authorities should be allowed sporadically to select a single defendant or a single class of defendants for prosecution because of personal animosity or some other illegitimate reason. ${ }^{3}$

The rationale supporting these attacks derives from the doctrine originating in $Y i c k W o$ v. Hopkins: ${ }^{4}$

Though the law itself be fair on its face and impartial in appearance, yet, if it is applied and administered by public authority with an evil eye and an unequal hand, so as prac-

1 Two Guys, Inc. v. McGinley, 366 U.S. 582 (1961); McGowan v. Maryland, 366 U.S. 420 (1961). But see Terry Carpenter, Inc. v. Wood, 177 Neb. 515, 529-30, 129 N.W.2d 475, 482-83 (1964) (concurring opinion) (The "real purpose [of such laws] is to protect narrow commercial interests, influenced by the fierce competition between the discount store and the downtown merchants."); cf. Skag-Way Dep't Stores v. City of Omaha, 179 Neb. 707, 140 N.W.2d 28 (1966).

2 See Moss v. Hornig, 314 F.2d 89 (2d Cir. 1963); Whitney Stores, Inc. v. Summerford, 280 F. Supp. 406 (D.S.C. 1968); Epstein v. Maddox, 277 F. Supp. 613 (N.D. Ga. 1967), aff'd, 401 F.2d 777 (5th Cir. 1968); Zayre of Georgia, Inc. v. City of Atlanta, 276 F. Supp. 892 (N.D. Ga. 1967); Gibson Products Co. v. Lowe, 440 S.W.2d 793 (Ky. 1969); City of Ashland v. Heck's, Inc., 407 S.W.2d 421 (Ky. 1966); People v. Utica Daw's Drug Co., 16 App. Div. 2d 12, 225 N.Y.S.2d 128 (1962) ; People v. Tornatore, 46 Misc. 2d 908, 261 N.Y.S.2d 474 (Poughkeepsie City Ct. 1965); People v. Paine Drug Co., 39 Misc. 2d 824, 241 N.Y.S.2d 946 (Monroe County C.t. 1963), rev'd, 22 App. Div. 2d 156, 254 N.Y.S.2d 492 (1964), aff'd, 16 N.Y.2d 503, 208 N.E.2d 176, 260 N.Y.S.2d 444, cert. denied, 382 U.S. 838 (1965); People v. Pam, 38 Misc. 2d 296, 238 N.Y.S.2d 363 (New York City Crim. Ct. 1963), aff'd, 43 Misc. 2d 357, 250 N.Y.S.2d 877 (App. T. 1964); City of South Euclid v. Bondy, 192 N.E.2d 139 (S. Euclid, Ohio Mun. Ct. 1963); Bargain City U.S.A., Inc. v. Dilworth, 407 Pa. 129, 179 A.2d 439 (1962).

3 People v. Utica Daw's Drug Co., 16 App. Div. 2d 12, 17-18, 225 N.Y.S.2d 128, 133 (1962).

4118 U.S. 356 (1886). A municipal ordinance rendered unlawful the operation of a laundry without the consent of a board of supervisors unless the building housing the operation was constructed of brick or stone. Only Chinese laundry operatorsand one non-Chinese operator-were denied the required permission and arrested for violation of the ordinance. Although not passing on the validity of the ordinance, the Court held that the discriminatory refusal to issue permits denied the Chinese petitioners equal protection. 
tically to make unjust and illegal discriminations between persons in similar circumstances, the denial of equal justice is still within the prohibition of the Constitution.

To substantiate a denial of equal protection based on discriminatory enforcement requires more than proof of mere nonenforcement of a statute against others, ${ }^{6}$ mere laxity of enforcement, ${ }^{7}$ or the "conscious exercise of some selectivity in enforcement." 8 Rather, the enforcement must be shown to contain an "element of intentional or purposeful discrimination." 9

In Zayre of Georgia, Inc. v. City of Marietta, ${ }^{10}$ three retail department stores, one intervening, sought to enjoin the cities of Marietta and Smyrna, Georgia, from discriminatory enforcement of the Georgia Sunday closing law. ${ }^{11}$ Plaintiffs contended that they were denied equal protection of the law because threats of enforcement and revocation of their business licenses were directed against them but not against other businesses competitively selling all or some of the same items.

The district court in an unreported opinion issued a temporary restraining order, ${ }^{12}$ and subsequently a nearly identical preliminary injunction, ${ }^{13}$ prohibiting the defendants from enforcing the closing

5 Id. at 373-74. Similar language appears in Sunday Lake Iron Co. v. Wakefield, 247 U.S. 350,352 (1918) :

The purpose of the equal protection clause . . . is to secure every person . - against intentional and arbitrary discrimination, whether occasioned by express terms of a statute or by its improper execution through duly constituted agents.

${ }^{6}$ See, e.g., Moss v. Hornig, 314 F.2đ 89, 92 (2d Cir. 1962).

7 See, e.g., State v. Hicks, 213 Ore. 619, 637, 325 P.2d 794, 802 (1958).

8 Oyler v. Boles, 368 U.S. 448, 456 (1962).

${ }^{9}$ Snowden y. Hughes, 321 U.S. 1, 8 (1944). The discrimination must be "[r]ooted in design and not derive merely from error or fallible judgement." Id. at 15 (Frankfurter, J., concurring). The burden of proof on one alleging discriminatory enforcement is unquestionably heavy. See, e.g., People v. Utica Daw's Drug Co., 16 App. Div. 2d 12, 19, 225 N.Y.S.2d 128, 135 (1962).

10416 F.2d 251 (5th Cir. 1969), cert. denied, 397 U.S. 918 (1970).

11 Ga. Code ANn. \$26-6905 (1935). 1968 GA. ACTS AND Resolutions 1249, 1337, $\S 2$ enacted the Criminal Code and recodified $\$ 26-6905$ as $\$ 26-9908$.

Any person who shall pursue his business or the work of his ordinary calling on the Lord's day, works of necessity or charity only excepted, shall be guilty of a misdemeanor.

12 The Fifth Circuit quoted the district court order:

[D] efendants . . are temporarily restrained from enforcing Section 26-6905 of the Code of Georgia of 1933 in a discriminatory manner and from revoking business licenses by reason of the violation of said Code Section in a discriminatory manner. This . . o order is not intended to prohibit the enforcement of Section 26-6905 . . nor to prohibit the revocation of business licenses by reason of its violation, but rather it orders that such enforcement be on a nondiscriminatory basis . . . .

416 F.2d at 252-53.

The order is reproduced in full in Petitioners' Brief for Certiorari at 20, Zayre of Georgia, Inc. v. City of Marietta, 397 U.S. 918 (1970) [hereinafter cited as Petitioners' Brief].

13 Reproduced in Petitioners' Brief 20-22. 
law and from revoking business licenses in a discriminatory manner. After an unsuccessful attempt to obtain enforcement of the injunction, plaintiffs sought further relief through contempt proceedings, alleging that other persons, professions, and businesses ${ }^{14}$ not covered by the statutory exemption for "works of necessity or charity" ${ }^{15}$ were permitted to stay open and conduct business in violation of the statute. The court orally declined to issue a contempt citation, stating that the injunction related only to discriminatory enforcement between competing merchants, and adhered to this interpretation in its subsequent denial of plaintiffs' formal motion to amend and broaden the preliminary injunction already in effect. ${ }^{16}$

The Fifth Circuit affirmed the denial of this motion, agreeing with the district court that plaintiffs lacked standing to assert a further denial of equal protection. ${ }^{17}$ It found that the principle of Yick $W_{0}$ was inapplicable because the plaintiffs had demonstrated no discrimination between businesses similarly situated beyond that justifying the preliminary injunction. ${ }^{18}$ But the court was able to find an absence of discrimination only by construing the phrase "similarly situated" to encompass only those businesses "in direct competition" 19 with the plaintiffs.

Judge Boyle dissented, arguing that the court had misconstrued the phrase and that a determination of which businesses or individuals are similarly situated must be made with reference to the applicable

14 Radio stations, newspapers, real estate agents, antique merchants, theaters, pet shops, florists, funeral directors, television repairmen, ministers, and aircraft manufacturing were noted. See id. 24.

15 Ga. Code AnN. \$26-6905 (1935).

16 Petitioners' Brief 23-26. The order granting the preliminary injunction, however, contains no explicit limitation on the discrimination prohibited. In summarizing the evidence of nonenforcement, the district court noted the Sunday operations of not only drug stores selling competitive consumer goods but also drive-in groceries. Id. 21. One reason for the court's refusal to grant the requested relief may be that plaintiffs referred in their original complaint only to businesses selling competitive merchandise. In denying the motion for expanded relief, the district court stated that "in the suit as originally filed, no such relief was sought or granted." Id. 24. The court appeared to ignore its holding in a prior injunction claim against the city of Atlanta. In Zayre of Georgia, Inc. v. City of Atlanta, 276 F. Supp. 892 (N.D. Ga. 1967), the court issued an order in terms substantially similar to those in the instant case. But the court's recitation of the stipulated facts indicated that the stores affected by the order were not limited to those in direct economic competition with the plaintiff.

17 The court of appeals quoted with approval the district court's arguments for denying the plaintiffs' motion to enlarge the scope of the injunction:

"[B]y their motion to enlarge the plaintiffs do not complain of discriminatory enforcement against them. What they do complain of is non-enforcement against other professions and trades in which plaintiffs are apparently not engaged. There is, of course, a great difference between discriminatory enforcement of a statute and non-discriminatory non-enforcement. . . .

"Such being the situation, it is difficult to see how the plaintiffs have standing to assert the charges contained in their motion."

416 F.2d at 253.

18 Id. at $253-54$.

${ }^{19} \mathrm{Id}$. 
statute. Because the closing law applied by its terms to "[a]ny person," those similarly situated were "all persons pursuing their regular business or calling" on Sunday, unless engaged in works of necessity or charity. Thus the plaintiffs were entitled to an injunction prohibiting "any discrimination whatsoever" in the enforcement of the statute, regardless of the absence of direct competition between businesses. ${ }^{20}$

This Comment contends that the court erred in its restrictive reading of the phrase "similarly situated," and that the approach and result of the dissent are more consonant with sound constitutional law. Had the court granted the expanded relief sought by the plaintiffs, it would have reflected more accurately the state legislature's intent and perhaps encouraged a reevaluation of the Sunday closing law.

\section{The Definition of "Similarly Situated"}

Given that plaintiffs had been singled out for prosecution from other businesses open on Sunday, ${ }^{21}$ the court should have looked to the class covered by the statutory prohibition to determine the lawfulness of this selective enforcement.

[T] he concept of equal protection has been traditionally viewed as requiring the uniform treatment of persons standing in the same relation to the governmental action questioned or challenged. ${ }^{22}$

The governmental action challenged in Zayre was the enforcement of the Sunday closing law. A determination of the class of persons and businesses "standing in the same relation" to this action must be based upon the law's intended scope. ${ }^{23}$ The declared policy of the

20 Id. at 254-55 (Boyle, J., dissenting). The dissent also noted that certain of the businesses allowed to remain open on Sunday had been held by Georgia courts to be subject to the Sunday closing law. Id. at 255. To demonstrate the broad sweep of the law, the dissent quoted the Supreme Court of Georgia:

It [the Sunday closing law] applies alike to all business, vocations, and occupations. . . . It is universal, and rigidly impartial, making no discrimination whatever . . . It puts no obstacle in the way of trade or its operations which is not encountered by every other class of worldly business or employment.

Id. at 255 n.2 (quoting Fennington v. State, 90 Ga. 396, 399, 17 S.E. 1009, 1010 (1892), aff'd sib nom. Hennington v. Georgia, 163 U.S. 299 (1896)).

21 Issuance of the preliminary injunction required proof of such discrimination. See text accompanying notes 6-9 supra. For a discussion of the problems in proving discriminatory enforcement, see Comment, The Right to Nondiscriminatory Enforcement of State Penal Laws, 61 ColvM. L. Rev. 1103, 1122-30 (1961).

22 Reynolds v. Sims, 377 U.S. 533, 565 (1964).

23 See Snowden v. Hughes, 321 U.S. 1,8 (1944) ("The unlawful administration . . of a state statute fair on its face, resulting in the unequal application to those who are entitled to be treated alike, is not a denial of equal protection unless there is . . . present in it an element of intentional or purposeful discrimination.") (emphasis added) ; Weisberg v. Powell, 417 F.2d 388, 392 (7th Cir. 1969) (Equal protection was denied by giving ballot preferences to certain candidates for public office because "[a]11 the candidates were entitled, under the state laze, to be treated 
Georgia legislature is clear from the statute: with the exception of works of charity and necessity, all business activity and ordinary work is to cease on Sunday. The statute nowhere distinguishes between competitive and noncompetitive businesses, the distinction relied upon by the Fifth Circuit in upholding the district court's refusal to enlarge the scope of the injunction. Because all businesses stand in the same relation to the statute, they are entitled to uniform, nondiscriminatory treatment under its directive.

The Zayre court's erroneous analysis is evidenced by the following language, quoted with apparent approval by the court, from the district court's denial of plaintiffs' motion to expand the preliminary injunction:

"So far as appears . . . the plaintiffs themselves, if they care to do so, may [on Sunday] operate a funeral parlor, a radio station, a pet shop, a florist shop or a business in any of the other categories complained of on the same basis as all other persons." 24

Behind this limitation of the equal protection clause to competitive businesses lies an incorrect interpretation of Yick Wo. The Zayre court relied on the fact that $Y i c k W_{0}$ involved discrimination between virtually identical laundries in the enforcement of a statute. ${ }^{25}$ But the persons similarly situated in $Y i c k W_{0}$ were so nearly identical because of the narrow scope of the statute itself: it applied to laundry operators exclusively. ${ }^{26}$ The $Y i c k$ Wo result is thus consistent with a rationale emphasizing the scope of the statute itself in defining "similarly situated." Competitive similarities between businesses should not have claimed the court's attention in Zayre, where the statute encompassed within its prohibition "any person." This interpretation of Yick $W o$ is reflected in Judge Boyle's conclusion:

The fact that a retail merchant is more "similarly situated" with other retail merchants, for example, than he is with a florist or a pet shop operator, does not compel the conclusion that the retail merchant and the florist are not "similarly situated" as far as this statute is concerned. To hold otherwise is to read Yick Wo v. Hopkins . . . too narrowly. ${ }^{27}$

alike.") (emphasis added); LaFave, The Police and Nonenforcement of the LawPart I, 1962 WIs. L. REv. 104, 135 (impermissible classifications include those "bearing unequally on persons similarly situated with respect to the subject ntatter of the law") (emphasis added). See also Distelhorst v. Day \& Zimmerman, Inc., 58 F. Supp. 334, 335 (S.D. Iowa 1944), appeal dismissed by consent of parties, 150 F.2d 541 (8th Cir. 1945) (In determining whether employees were similarly situated for purposes of bringing an action under the Fair Labor Standards Act of 1938, similarity "zerith reference to their employer" is sufficient despite differences in the nature of employments.) (emphasis added).

24416 F.2d at 253.

$25 I d$. at $253-54$.

26 See 118 U.S. at $357-58$.

27416 F.2d at 255 (emphasis added). 
In Davis v. Board of Education, ${ }^{28}$ cited by the Zayre court in support of its equal protection theory, ${ }^{29}$ the Fifth Circuit described an approach consistent with that urged herein. The court affirmed the dismissal of the complaint of certain school children and their parents seeking to force the state to allow the transfer of the children and corresponding state funds from one county school system to another. The court held that to establish a denial of equal protection based upon the allegedly discriminatory transfer denial, the plaintiffs had to show that they were similarly situated with those for whom transfer was permitted..$^{30}$ To prove such a similar situation, it was necessary to establish either that the plaintiffs had satisfied the provisions of the statute governing such procedures, or that others had not satisfied the provisions but were granted permission to transfer nevertheless. ${ }^{31}$ In determining which persons were similarly situated, the court thus looked to the statute itself and its intended scope.

The Kentucky Court of Appeals, in a case practically on all fours with Zayre, correctly interpreted $Y i c k W o$ and enjoined the defendant city from enforcing a broad Sunday closing law against the plaintiff department store unless such enforcement was part of a just and equal program of statutory enforcement against all known violators, "some of which sell many of the same types of merchandise" as the plaintiff. ${ }^{32}$ In a more recent decision, ${ }^{33}$ the same court reversed the dismissal of a complaint seeking uniform enforcement of a Sunday closing law against all offenders. The court did, however, affirm dismissal of that portion of the complaint alleging discrimination based on the enforcement of the closing law against the plaintiff and the nonenforcement of the prohibition against hunting on Sunday. The court noted that merchants and hunters are properly in different classes and are "so designated and treated in the statute." 34

In sum, the Zayre court failed to recognize that, when the administration of a statute fair on its face is challenged, the determination of parties similarly situated must be made with reference to the scope of the statute involved. ${ }^{35}$

28408 F.2d 1014 (5th Cir. 1969).

$29416 \mathrm{~F} 2 \mathrm{~d}$ at 254 .

30408 F.2d at 1015.

31 Id. at 1016.

32 Ashland v. Heck's, Inc., 407 S.W.2d 421, 421-22 ( $\mathrm{Ky} .1966$ ) (emphasis added). The court also relied upon Covington v. Gausepohl, $250 \mathrm{Ky}$. 323, 62 S.W.2d 1040 (1933), in which a municipal ordinance prohibiting the placing of merchandise on sidewalks was enforced only against plaintiff and other storekeepers and not against farmers, "hucksters," and "other market people." The Covington court relied on Yick Wo to enjoin the city's enforcement of the ordinance in a discriminatory manner, and treated the above classes as similarly situated.

33 Gibson Products Co. v. Lowe, 440 S.W.2d 793 (Ky. 1969).

34 Id. at 795 (emphasis added).

35 See Kotch v. Board of River Port Pilot Comm'rs, 330 U.S. 552, 557 (1947) ("Yick Wo's case, as other cases have demonstrated, was tested by the language of the law there considered and the administration there shown."). 


\section{The Boundaries of Prosecutorial Discretion}

Although the opinion is silent on this point, Zayre may be interpreted as a recognition of the broad scope afforded the doctrine of prosecutorial discretion. $^{36}$ The court never mentioned the prosecutor's discretion, but it was apparently untroubled by disparate treatment of "persons" under the statute, and at the close of its opinion it did remark:

If appellants are contending . . . that they should be immunized from prosecution under the statute unless and until other violators are brought to justice, then their attack also must fail under the circumstances here.

The federal courts have no general supervisory power over the operation of state and local governments. ${ }^{37}$

If indeed the court had prosecutorial discretion in mind, its reliance was misplaced, for a reasonable allowance for such discretion would legitimatize neither the discriminatory enforcement action challenged in Zayre nor potential discriminatory action left unchecked by the limited restrictions on enforcement enunciated by the court.

Some courts have held that the prosecutor's discretion in enforcing a statute is as broad as the legislature's in enacting it, and that the prosecutor may therefore make any classification which would be permissible if made by the legislature. ${ }^{38}$ It has been suggested ${ }^{39}$ that this conclusion flows from Kotch v. Board of River Port Pilot Commissioners, ${ }^{40}$ in which the Supreme Court upheld against an attack based on $Y i c k$ Wo the Louisiana pilotage law pursuant to which the

36 See, e.g., Washington v. United States, 401 F.2d 915, 925 (D.C. Cir. 1968). See generally LaFave, supra note 23; LaFave, The Police and Nonenforcement of the Laze-Part II, 1962 Wis. L. REv. 179.

37416 F.2d at 254.

38 Taylor v. City of Pine Bluff, 266 Ark. 309, 289 S.W.2d 679, cert. denied, 352 U.S. 894 (1956). The court held that because a Sunday closing statute applicable only to grocery stores would have been valid, the enforcement of a general closing law against such stores exclusively did not deny equal protection to a convicted grocer. In Two Guys, Inc. v. McGinley, 179 F. Supp. 944, 953 (E.D. Pa. 1959) (3-judge court), aff'd, 366 U.S. 582 (1961), the district court stated as a "controlling constitutional principle" that discriminatory behavior by administrative officers does not deny equal protection "unless equivalent action by the state legislature would ... In affirming, the Supreme Court did not discuss the existence or validity of such a principle.

39 Comment, supra note 21 , at 1118 .

40330 U.S. 552 (1947). Another possible basis for such a position, cited in Two Guys, Inc. v. McGinley, 179 F. Supp. 944, 953 (E.D. Pa. 1959) (3-judge court), aff'd, 366 'U.S. 582 (1961), is the following statement from Snowden v. Hughes, 321 U.S. 1, 11: "If the action of the [State Canvassing] Board is official action it is subject to constitutional infirmity to the same but no greater extent than if the action were taken by the state legislature." In context, however, this language appears to be used in a quantitative rather than a qualitative sense to indicate that the illegality of the Board's action under its governing statute neither adds to nor detracts from its constitutional validity. 
state governor appointed pilots from those satisfying an apprenticeship requirement. Under the law, incumbent pilots selected apprentices, and plaintiffs complained that only friends and relatives of the pilots were selected. The Court upheld the scheme because in view of the unique status of the institution of pilotage in Louisiana history it could not determine that the entire selection procedure was not reasonably related to the legitimate objective of a safe and efficient pilotage system. $^{41}$

But Kotch should be distinguished from the instant situation. Kotch involved discrimination in the process of awarding licenses, not the discriminatory imposition of criminal penalties, and the administrative discretion there challenged was expressly conferred by the statute itself. Most important, the Court apparently treated the entire system as legislative in nature. ${ }^{42}$

Even if the permissible scope of discretion exercised by those charged with the enforcement of the law is more restricted than the legislature's discretion in enacting the law, "there remains an area of unequal enforcement occasioned by discriminatory judgment of the police and prosecutors that is not violative of the equal protection clause." ${ }^{43}$ Prosecutorial discretion or selectivity in enforcement is often necessary because limitations on funds and manpower prohibit the enforcement of all laws against all offenders. ${ }^{44}$ The crucial question is the proper breadth of this discretion. As one court has stated:

Selective enforcement may be justified when the meaning or constitutionality of the law is in doubt and a test case is needed to clarify the law or establish its validity. Selective enforcement may also be justified when a striking example or a few examples are sought in order to deter other violators, as part of a bona fide rational pattern of general enforcement, in the expectation that general compliance will follow and that further prosecutions will be unnecessary. It is only when the selective enforcement is designed to discriminate against the persons prosecuted, without any intention to follow it up by general enforcement against others, that a constitutional violation may be found..$^{45}$

\section{U.S. at $563-64$.}

42 The Court stated that it could only assume that the Iouisiana legislature had weighed the possibility of the evils of nepotism against the need for a closely knit pilotage system and had decided in favor of the latter. Id. Subsequent cases have cited Kotch as authority for sustaining a legislative classification if reasonably related to a valid state objective. Turner v. Fouche, 396 U.S. 346, 362 n.24 (1970); Kramer v. Union Free School Dist., 395 U.S. 621, 636 (1969) (dissenting opinion).

43 Comment, supra note 21 , at 1119.

44 Cf. Oyler v. Boles, 368 U.S. 448, 456 (1962).

45 People v. Utica Daw's Drug Co., 16 App. Div. 2d 12, 21, 225 N.Y.S.2d 128, 136 (1962). See also Note, Discriminatory Lave Enforcenent and Equal Protection From the Law, 59 YALE L.J. 354, 357 (1950). 
So far as appears from the opinion in Zayre, the prosecutor's decision to enforce the Georgia law selectively was not supported by any of the criteria noted above. The meaning of the Georgia Sunday closing law is free from doubt. The selection of plaintiffs and other retail department stores cannot be viewed as part of a rational pattern of general law enforcement in view of the universality of the legislative command. ${ }^{46}$ The selective deployment of limited resources among various laws, or against some persons covered by a particular law, may be necessary to effectuate a statutory policy. But such selective enforcement is qualitatively different from the action taken against Zayre and its co-plaintiffs-action which, in effect, usurped the legislative function and frustrated the declared policy of the legislative program. ${ }^{47}$

In his dissent, Judge Boyle recognized the validity in many instances of prosecutorial discretion but cautioned that it is not the prosecutor's "prerogative to carve out exceptions to statutes of universal or general application." 48 In fact, the problem implicit in granting discretion to the prosecutor in Sunday closing law situations may be the product of doubts about the extent of a consensus as to the validity of those laws.

The inequality tolerated by this judicial hands-off policy is particularly acute where a law has ceased to reflect contemporary public opinion: it is then that enforcement is sporadic and most likely to be discriminatory. ${ }^{49}$

\section{8 (1966). \\ ${ }^{46}$ But see Skag-Way Dep't Stores v. City of Omaha, 179 Neb. 707, 140 N.W.2d}

47 But see Bargain City U.S.A., Inc. v. Dilworth, 407 Pa. 129, 179 A.2d 439 (1962) (by implication). The argument implicit in Bargain City, in which a closing law was admittedly enforced only against large retail establishments, is that because such establishments interfere most with the legislative policy of securing a day of rest and relaxation, exclusive enforcement, necessitated by limited resources, best effectuates the statutory purpose.

But there is some question whether even the legislature could make such a classification. Compare Terry Carpenter, Inc. v. Wood, 177 Neb. 515,129 N.W.2d 475 (1964), witth Bertera's Hopewell Foodland, Inc. v. Masters, $428 \mathrm{~Pa} .20,236$ A.2d 197 (1967), appeal dismissed, 390 U.S. 597 (1968). In any event, the Georgia legislature has made no such statutory declaration of purpose and, if enforcement against plaintiffs was based on the above reasoning, the initial nonenforcement against direct competitors indicates that this degree of "purpose-effectuating" discretion should have been denied the Georgia law enforcement officials. Further,

sporadic enforcement can hardly be explained by a desire to effectuate the law's purpose, since the law, vitiated to the extent of its nonenforcement, has ceased to exert any significant effect on the pattern of community behavior.

Note, supra note 45 , at 354 n.4.

48416 F.2d at 255.

[T] his Court is of the opinion that neither [McGowan nor Two Guys] stands for the proposition that municipalities may choose to carve out exceptions via selective enforcement of the statute.

Zayre of Georgia, Inc. v. Atlanta, 276 F. Supp. 892, 894 (N.D. Ga. 1967).

49 Note, supra note 45 , at 354 . 


\section{CoNCLUSION}

The Fifth Circuit's refusal to expand the preliminary injunction perhaps reflects its conclusion that "federal courts have no general supervisory power over the operation of state and local governments." 50 The preliminary injunction did alleviate the most severe hardship-economic advantage to their competitors-of the discrimination against the plaintiffs. The court may have feared that expansion of the injunction would result in increased federal supervision of state enforcement mechanisms.

But however laudatory the Fifth Circuit's reluctance to oversee the operation of local government, the court should not have deemed this consideration controlling. First, it resulted in an interpretation which ignored the statute's own conception of persons similarly situated while giving tacit approval to an overly expansive concept of selective enforcement. $^{51}$ Second, granting the expanded relief sought pursuant to the statute would have had the incidental yet desirable effect of prompting legislative reevaluation of the stated justifications ${ }^{52}$ for the Sunday closing law. In accordance with such a grant of expanded injunctive relief, the statute would be enforced either uniformly, against all types of businesses and occupations, or not at all. ${ }^{53}$ In either instance, public opinion and reaction, whether for or against the enforcement decision, might well provide intelligible guidelines for the legislature to follow in considering this traditional area of penal legislation. ${ }^{54}$

50416 F.2d at 254. The district court, in granting the preliminary injunction, noted that "the Court does not desire to interfere in such matters. It is indeed unpleasant and burdensome to the Court to be required to do so." Petitioners' Brief 22.

51 One commentator has noted the danger posed by statutes vesting administrative officers with extensive discretion. Such a statute

injects into the governmental wheel so much free play that in the practical course of its operation it is likely to function erratically-responsive to whim or discrimination unrelated to any specific determination of need by the responsible policy-making organs of society-and to result in a significant number of impermissible public-versus-private-interest resolutions . . . .

Note, The Void-for-Vagueness Doctrine in the Supreme Court, 109 U. PA. L. REv. $67,90(1960)$. The same potential for abuse is inherent in nonstatutory prosecutorial discretion.

52 See McGowan v. Maryland, 366 U.S. 420, 450 (1961).

53 Such uniform treatment would not require that every violator be detected and prosecuted, as the district court, in denying the motion for expanded relief, Petitioners' Brief 26, assumed, but only that a rational pattern for such action, geared to effectuate compliance by all covered by the statute, be established.

54

[A] court injunction against the discriminatory enforcement would tend to bolster the "necessary" law by compelling enforcement officials either to generalize their operations or face inquiry and discipline at the hands of an exasperated legislature.

Note, supra note 45 , at 359 . 